\title{
PASANG SURUT HUBUNGAN ANTARA MAHKAMAH AGUNG DENGAN KOMISI YUDISIAL DALAM SISTEM KETATANEGARAAN REPUBLIK INDONESIA
}

\author{
Muhammad Fauzan \\ Fakultas Hukum dan Program MIH UNSOED \\ Email : fauzanhtn@yahoo.co.id
}

\begin{abstract}
The relationship between the Supreme Court by the Judicial Commission in the Republic of Indonesia system is not harmonious, this is due to the first, the disharmony between the law on judicial power, including the law on Judicial Power, the law on the Supreme Court, the law on Constitutional Court and the law on the Judicial Commission. Both of the leadership character that exist in the Supreme Court and the Judicial Commission were too emphasizes in ego that one sector feel more superior than the others. To create a harmonious relationship between Supreme Court and J udicial Commission can be done by establishing intensive communication between both of them and by improvement in legislation.
\end{abstract}

Keywords : relation, Supreme Court, Judicial Commission

\begin{abstract}
Abstrak
Hubungan antara Mahkamah Agung dengan Komisi Yudisial dalam sistem ketatanegaraan Republik Indonesia tidak terlalu harmonis, hal ini disebabkan pertama, adanya disharmonisasi antara perauran perundang-undangan di bidang kekuasaan kehakiman yang meliputi undang-undang tentang Kekuasaan Kehakiman, undang-undang tentang Mahkamah Agung, undang-undang Mahkamah Konstitusi dan undang-undang tentang Komisi Yudisial. Kedua karakter kepemimpinan yang ada di Mahkamah Agung dan Komisi Yudisial yang terlalu mengedepankan ego bahwa salah satu merasa lebih superior dari yang lain. Untuk menciptakan hubungan yang harmonis antara Mahkamah Agung dengan Komisi Yudisial dapat dilakukan dengan membangun komunikasi intensif antara keduanya dan penyempurnaan peraturan perundang-undangan.
\end{abstract}

Kata kunci : Hubungan, Mahkamah agung, Komisi Yudisial

\section{Pendahuluan}

Perubahan Undang Undang dasar (UUD) 1945 yang telah melalui proses amandemen I sampai ke IV telah membawa perubahan yang sangat fundamental terkait dengan sistem ketatanegaraan Republik Indonesia, eksisteni lembaga negara utama berubah, yakni dengan hilangnya Dewan Pertimbangan Agung (DPA) dan lahirnya lembaga negara baru seperti Mahkamah Konstitusi (MK), dan Komisi Yudisial, ${ }^{1}$ serta

Muhammad Fauzan, "Kewenangan Mahkamah Konstitusi Dalam Proses Impeachment Presiden Menurut Sistem Ketatanegaraan Republik Indonesia", J urnal Dinamika Hukum FH UNSOED Purwokerto, 11 (1) Januari 2011, hlm. 69
Dewan Perwakilan Daerah (DPD) di samping masih diakuinya keberadaa lembaga utama lainnya seperti Mahkamah Agung (MA), Dewan Perwakilan Rakyat (DPR), Majaleis Permusyawaratan Rakyat (MPR), dan Badan Pemeriksa Keuangan (BPK).

Eksistensi Mahkamah Agung (MA) dalam sejarah perjalanan ketatanegaraan Republik Indonesia (RI) merupakan salah satu lembaga negara yang selalu ada dan diatur dalam konstitusi yang pernah berlaku di Indonesia. Hal tersebut dapat dilihat dari perkembangan konstitusi yang pernah berlaku, yakni dimulai sejak UUD 1945 yang disahkan pada Tanggal 18 Agus- 
tus 1945 (termasuk UUD 1945 setelah Dekrit 5 J uli 1959), Konstitusi Republik Indonesia Serikat (KRIS) 1949, Undang Undang Dasar Sementara (UUDS) Tahun 1950 dan UUD 1945 Hasil Amandemen.

Eksistensi MA dalam UUD 1945 yang disahkan pada tanggal 18 Agustus 1945, dapat di temukan dalam ketentuan Pasal 24 ayat (1) yang mengamanatkan bahwa "Kekuasan kehakiman dilakukan oleh sebuah Mahkamah Agung dan lain-lain badan kehakiman menurut undang-undang". Sedangkan dalam Konstitusi RIS 1949 dapat dijumpai dalam ketentuan Pasal 113 yang menentukan bahwa: “...adalah suatu Mahkamah Agung Indonesia yang susunan dan kekuasaannya diatur dengan undang-undang federal". Bahkan Konstitusi RIS 1949 sudah mengatur mengenai organisasi MA, hal ini sebagaimana diamanatkan dalam Pasal 114 menentukan bahwa:

1. Untuk pertama kali dan selama undang-undang federal belum menetapkan lain, Ketua, Wakil-Ketua dan anggota-anggota Mahkamah Agung diangkat oleh Presiden setelah mendengarkan Senat. Pengangkatan itu adalah untuk seumur hidup; ketentuan ini tidak mengurangi jang ditetapkan dalam ayat-ayat yang berikut.

2. Undang-undang federal dapat menetapkan, bahwa Ketua, Wakil-Ketua dan anggota-anggota Mahkamah Agung diberhentikan, apabila mencapai usia yang tertentu.

3. Mereka dapat dipecat atau diberhentikan menurut cara dan dalam hal jang ditentukan oleh undang-undang federal.

4. Mereka dapat diberhentikan oleh Presiden atas permintaan sendiri.

Eksistensi MA juga diamanatkan di dalam UUDS 1950 Pasal 78 dan Pasal 79. Pasal 78 menentukan bahwa, "Susunan dan kekuasaan Mahkamah Agung diatur dengan undang-undang". Kemudian Pasal 79 menentukan bahwa:

1. Ketua, Wakil-Ketua dan Anggota-anggota Mahkamah Agung diangkat menurut aturanaturan yang ditetapkan dengan undangundang.
2. Pengangkatan itu adalah untuk seumur hidup; ketentuan ini tidak mengurangi yang ditetapkan dalam ayat-ayat yang berikut.

3. Undang-undang dapat menetapkan, bahwa Ketua, Wakil-Ketua dan Anggota-anggota Mahkamah Agung diberhentikan, apabila mencapai usia yang tertentu.

4. Mereka dapat dipecat atau diberhentikan menurut cara dan dalam hal yang ditentukan oleh undang-undang.

5. Mereka dapat diberhentikan oleh Presiden atas permintaan sendiri.

Berdasarkan ketentuan-ketentuan tersebut di atas, baik menurut UUD 1945 sebelum diamandemen maupun berdasarkan Konstitusi RIS dan UUDS 1950, ketentuan mengenai MA dalam Konstitusi RIS 1949 dan UUDS 1950 dapat disimpulkan bahwa pengaturan mengenai MA dalam UUD 1945 sebelum diamandemen jauh lebih sederhana. Hal lain yang dapat disimpulkan, bahwa ketentuan tentang MA baik dalam Konstitusi RIS 1949 dan UUDS 1950 mempunyai kemiripan substantif, kalau tidak boleh dikatakan sama persis.

Hal berbeda justru diatur pada UUD 1945 hasil amandemen, bahwa eksistensi mengenai MA diatur dalam Pasal 24 ayat (2) dan Pasal 24 A termasuk juga dalam Pasal 14 ayat (1) yang mengatur tentang pemberian grasi dan rehabilitasi dari Presiden. Pasal 24 ayat (2) UUD 1945 hasil amandemen menyatakan secara tegas bahwa, "Kekuasaan kehakiman dilakukan oleh sebuah Mahkamah Agung dan badan peradilan yang berada di bawahnya dalam lingkungan peradilan umum, lingkungan peradilan agama, lingkungan peradilan militer, lingkungan peradilan tata usaha negara, ...". Sedangkan Pasal 24A UUD 1945 hasil amandemen menentukan bahwa:

1. Mahkamah Agung berwenang mengadili pada tingkat kasasi, menguji peraturan perundang-undangan di bawah undang-undang terhadap undang-undang, dan mempunyai wewenang lainnya yang diberikan oleh undang-undang.

2. Hakim agung harus memiliki integritas dan kepribadian yang tidak tercela, adil, profesional, dan berpengalaman di bidang hukum. 
3. Calon hakim agung diusulkan Komisi Yudisial kepada Dewan Perwakilan Rakyat untuk mendapatkan persetujuan dan selanjutnya ditetapkan sebagai hakim agung oleh Presiden.

4. Ketua dan wakil ketua Mahkamah Agung dipilih dari dan oleh hakim agung.

5. Susunan, kedudukan, keanggotaan, dan hukum acara Mahkamah Agung serta badan peradilan di bawahnya diatur dengan undang-undang.

Pengaturan tentang MA yang relatif baik dalam UUD 1945 hasil amandemen jika dibandingkan dengan 3 (tiga) UUD sebelumnya merupakan bukti komitmen normatif yang ingin mewujudkan kekuasaan kehakiman yang merdeka dalam rangka menegakan hukum dan keadilan sebagaimana tercermin dalam ketentuan Pasal 24 ayat (1) UUD 1945 hasil amandemen, yang menegaskan bahwa, "Kekuasaan kehakiman merupakan kekuasaan yang merdeka untuk menyelenggarakan peradilan guna menegakkan hukum dan keadilan".

Berdasarkan uraian tersebut di atas, maka dapat dikatakan bahwa urgensitas dari lembaga negara yang dinamakan MA mempunyai kualifikasi sebagai lembaga negara utama/pokok dalam sistem ketatanegaraan yang pernah dan sedang berlaku. Hal tersebut berbeda dengan eksistensi Komisi Yudisial (KY), karena dalam UUD yang pernah berlaku sebelum UUD 1945 hasil amandemen, keberadaan KY sama sekali tidak diatur.

KY dibutuhkan keberadaannya dalam sistem ketatanegaraan di beberapa negara karena disebabkan hal-hal berupa: pertama, lemahnya monitoring secara intensif terhadap kekuasaan kehakiman, karena monitoring hanya dilakukan secara internal saja; kedua, tidak adanya lembaga yang menjadi penghubung antara kekuasaan pemerintah (executive power) dan kekuasaan kehakiman (judicial power); ketiga, kekuasaan kehakiman dianggap tidak mempunyai efisiensi dan efektivitas yang memadahi dalam menjalankan tugasnya apabila masih disibukan dengan persoalan-persoalan tekhnis non-hukum; keempat, tidak adanya konsistensi putusan lembaga peradilan, karena setiap putusan kurang memperoleh penilaian dan pengawasan yang ketat dari sebuah lembaga khusus; dan kelima, pola rekruitmen hakim selama ini dianggap terlalu bias dengan masalah politik, karena lembaga yang mengusulkan dan merekrutnya adalah lembaga politik, yaitu presiden dan parlemen. ${ }^{2}$

Mencermati alasan-alasan tersebut di atas, maka dapat disimpulkan sebaliknya, bahwa keberadaan KY dalam sistem ketatanegaraan tidak diperlukan lagi manakala dipenuhi beberapa syarat-syarat yang menunjukan suatu kondisi sebagai berikut: pertama, monitoring terhadap kekuasaan kehakiman telah dilakukan secara secara intensif, baik monitoring yang di lakukan secara internal saja maupun eksternal; kedua, adanya lembaga yang menjadi Penghubung antara kekuasaan pemerintah (executive power) dan kekuasaan kehakiman (judicial power); ketiga, kekuasaan kehakiman telah dilaksankan secara efisiensi dan efektif serta mewadahi dalam menjalankan tugasnya dn tidak lagi disibukan dengan persoalan-persoalan tekhnis non-hukum; keempat, adanya konsistensi putusan lembaga peradilan, karena setiap putusan sudah memperoleh penilaian dan pengawasan yang ketat dari sebuah lembaga khusus; dan kelima, pola rekruitmen hakim tidak lagi terpengaruh oleh kekuatan-kekuatan politik.

Keberadaan KY di Indonesia di samping sedikit banyak disebabkan oleh hal-hal tersebut di atas, juga dapat dilihat dalam perspektif lain, yakni banyaknya carut marut pelaksanaan kekuasaan kehakiman yang sering dan bahkan tidak pernah "sepi" dari pengaruh kekuasaan pemerintah dan kakuasaan lainnya termasuk kekuasaan uang, yang telah mendorong pemikiran perlunya sebuah lembaga yang dapat "menjamin" kekuasaan kehakiman untuk dapat berjalan sesuai dengan tujuan dari hukum, yakni keadilan masyarakat. ${ }^{3}$ Kehadiran KY pada

Ahsin Thohari, Komisi Yudisial dan Reformasi Peradilan, J akarta: ELSAM, 2004, hlm. 144-145. Bandingkan juga dengan Ahsin Thohari, "Komisi Yudisial dalam Ketatanegaraan Indonesia", Majalah Pakar J akarta, II (6) J uni 2003, hlm. 42-43

Muhammad Fauzan, "Eksistensi Komisi Yudisial Dalam Struktur Ketatanegaraan Republik Indonesia dan Yang Seharusnya Diatur dalam Peraturan-Perundang", Jurnal 
intinya justru untuk menghindarkan campur tangan kekuasaan eksekutif yaiut Presiden ke dalam Mahkamah Agung melalui mekanisme pengangkatan hakim agung ke KY maka Mahkamah Agung terbebas dari pengaruh kekuasaan eksekutif, oleh karenanya kekuasaan yang merdeka untuk menyelenggarakan peradilan yang dimiliki oleh Mahkamah Agung akan meningkat kualitasnya. ${ }^{4}$

KY dibentuk sebagai respon terhadap upaya menegakan reformasi di institusi peradilan, yang salam ini dianggap kurang baik. Selain itu untuk meminimalisasi interen politik dari anggota DPR di dalam memilih dan menentukan hakim agung di Mahkamah Agung. Mahkamah Agung adalah institusi peradilan yang independen dan seharusnya terlepas dari campur tangan dari kekuasaan manapun. Dengan KY, pencalonan hakim agung diharapkan dilakukan secara transparan, obyektif, dan dapat dipertanggungjawabkan. ${ }^{5}$ Bahkan J auh sebelum Komisi Yudisial lahir, para pemerhati dan praktisi hukum sebenarnya talah berupaya untuk membentuk sebuah lembaga khusus yang diharapkan dapat melaksankan fungsi-fungsi tertentu yang berhubungan dengan pelaksanaan kekuasaan kehakiman. Pada tahun 1968 saat pembahasan Rancangan Undang-Undang (RUU) Ketentuan-Ketentuan Pokok Kekuasaan Kehakiman, dimunculkan ide perlunya sebuah lembaga yang diberi nama Majlis Pertimbangan Penelitian Hakim (MPPH). Namun demikian politik hukum nasional, ternyata tidak menghendaki kelahiran lembaga tersebut, padahal secara ob-

Dinamika Hukum FH UNSOED Purwokerto, 8 (1) J anuari 2008, hlm. 44

4 Harjono, "Lembaga Negara Dalam UUD 1945", J urnal Konstitusi Republik Indonesia J akarta, 4 (2) J uni 2001, hlm. 17.

5 J imly Asshiddiqie, 2005, Lembaga Negara dan Sengketa Kewenangan Antar Lembaga Negara, J akarta: Konsorsium Reformasi Hukum Nasional (KRHN) bekerjasama dengan Mahkamah Konstitusi, hlm. 82 jektif fungsi $\mathrm{MPPH}^{6}$ tersebut sangat menjanjikan terbentuknya peradilan yang berwibawa. ${ }^{7}$

Kehadiran KY sebagai lembaga pengawas eksternal kekuasaan kehakiman, adalah agar melibatkan mesyarakat Indonesia di luar struktur resmi lembaga parlemen dalam proses pengangkatan, penilaian kinerja dan kemungkinan pemberhentian hakim. Dengan demikian diharapkan akan terwujud kekuasaan kehakiman yang merdeka dan bersifat imparsial (independent and impartial judicary) yang sekaligus diimbangi oleh prinsip akuntabilitas, kehadiran KY memberi harapan baru bagi pencari keadilan untuk mewujudkan lembaga peradilan yang bersih dan berwibawa. ${ }^{8}$

Pengaturan KY dalam sistem hukum tata negara positif RI diatur dalam Bab IX UUD 1945 hasil amandemen yang mengatur tentang Kekuasaan Kehakiman. KY dalam sistem ketatanegaraan RI juga merupakan lembaga negara baru, karena sebelumnya tidak pernah ada, hal tersebut sebagaimana diamanatkan di dalam Pasal 24B UUD 1945 yang menentukan bahwa :

1. Komisi Yudisial bersifat mandiri yang berwenang mengusulkan pengangkatan hakim agung dan mempunyai wewenang lain dalam rangka menjaga dan menegakkan kehormatan, keluhuran martabat, serta perilaku hakim.

2. Anggota Komisi Yudisial harus mempunyai pengetahuan dan pengalaman di bidang hukum serta memiliki integritas dan kepribadian yang tidak tercela.

3. Anggota Komisi Yudisial diangkat dan diberhentikan oleh Presiden dengan persetujuan Dewan Perwakilan Rakyat.

4. Susunan, kedudukan, dan keanggotaan Komisi Yudisial diatur dengan undang-undang.

6 Fungsi MPPH meliputi fungsi MPPH meliputi memberikan pertimbangan dan mengambil keputusan terakhir mengenai saran-saran dan/atau asal usul yang berkenaan dengan pengangkatan, promosi, kepindahan, pemberhentian, dan tindakan atau hukuman jabatan para hakim, yang diajukan baik oleh Mahkamah Agung mau pun Menteri Kehakiman.

Muhammad Fauzan, op.cit., hlm. 6

8 Devica Rully Masrur, "Implikasi Putusan Mahkamah Konstitusi Dalam Pengujian UU No. 22 Tahun 2004 Tentang Komisi Yudisial Terhadap Pengawasan Perilaku Hakim", J urnal Hukum Kebijakan Publik RES REPUBLICA FH UNS Surakarta, 1(1) September 2007, hlm. 25 
Secara umum, kedua fungsi KY yang diatur dalam Pasal 24B UUD 1945 tersebut relatif lebih sempit apabila dibandingkan dengan gagasan yang dikembangkan oleh Tim Kerja Terpadu Mengenai Pangkajian Pelaksanaan Ketetapan Majelis Permusyawaratan Rrakyat (MPR) Nomor X/ MPR/ 1998 tentang Pokok Pokok Reformasi Pembangunan dalam rangka Penyelamatan dan Normalisasi Kehidupan Nasional sebagai Haluan Negara dan Undang-Undang No. 35 Tahun $1999 .{ }^{9}$

Pengaturan KY dalam Bab IX yang mengatur tentang Kekuasaan Kehakiman, sama sekali tidak boleh dikatakan sebagai lembaga pelaku kekuasaan kehakiman, karena berdasarkan ketentauan Pasal 24 ayat (2) UUD 1945 hasil amandemen ditentukan bahwa Kekuasaan kehakiman dilakukan oleh sebuah Mahkamah Agung dan badan peradilan yang berada di bawahnya dalam lingkungan peradilan umum, lingkungan peradilan agama, lingkungan peradilan militer, lingkungan peradilan tata usaha negara, dan oleh sebuah Mahkamah Konstitusi.

Keberadaan KY dalam dalam prakteknya telah mengakibatkan pihak lain (baca: lembaga lain) seperti MA "gerah" dan tidak "nyaman" dalam kesehariannya, hal tersebut dikarenakan KY berdasarkan ketentuan Pasal 24B UUD 1945 hasil amandemen merupakan lembaga yang bersifat mandiri yang berwenang mengusulkan pengangkatan hakim agung dan mempunyai wewenang lain dalam rangka menjaga dan menegakkan kehor-matan, keluhuran martabat, serta perilaku hakim.

Wewenang lain yang dimiliki oleh $\mathrm{KY}$ dalam rangka menjaga dan menegakan kehormatan, keluhuran martabat, serta perilaku hakim telah berdampak hubungan antara MA dengan KY tidak harmonis, bahkan dalam tataran tertentu sering terjadi "perang pernyataan" antara MA dengan KY yang terkesan satu dengan lainnya saring "tidak akur". Yang satu merasa sebagai lembaga pemegang kekuasaan keahakiman yang kemandiriannya dijamin da-

Satya Arinanto, "Reformasi Hukum, Demokrasi, dan Hak Asasi Manusia", Jurnal Hukum dan Pembangunan Fakultas Hukum UI Jakarta, XXVIII (1-3) J anuari -J uni 1998, hlm. 124-125.
Iam UUD, dan oleh karenanya menjadi "haram" setiap aktivitas lembaga baru yang bernama KY untuk mengawasi perilaku hakim, karena hal tersebut daqpat mengancam kebebasan hakim yang bersifat universal.

Sementara pihak lain berpendapat bahwa keberadaan KY adalah dalam rangka mendukung terciptanya peradilan yang benar-benar dapat mencerminkan sebagai peradilan yang mempu menegakan hukum dan keadilan, oleh karena itu kewenangan KY tersebut, hakekatnya untuk menjawab pesimisme dan ketidakpercayaan masyarakat terhadap dunia peradilan. Tejadinya disharmonisasi hubungan antara MA dengan $K Y$ sedikit banyak telah mengakibatkan "tersendatnya" upaya mewujudkan peradilan yang bersih dan berkualitas, serta terbebas dari pengaruh kekuasaan pemerintah dan kekuasaan lain, termasuk kekuasaan uang dan politik.

Mencermati uraian di atas, maka tulisan ini hadir untuk menganalisis tentang hubungan antara Mahkamah Agung dengan Komisi Yudisial dalam sistem ketatanegaraan RI dan bagaimana seharusnya hubungan antara Mahkamah Agung dengan Komisi Yudisial pada masa yang akan datang.

\section{Pembahasan}

UUD 1945 hasil amandemen tidak memberikan kejelasan mengenai bagaimana hubungan yang seharusnya terjalin antara MA dengan KY. Hubungan antara kedua lembaga tersebut tersirat dari ketentuan Pasal 24B ayat (1) Komisi Yudisial bersifat mandiri yang berwenang me-ngusulkan pengangkatan hakim agung dan mempunyai wewenang lain dalam rangka menjaga dan menegakkan kehormatan, keluhuran martabat, serta perilaku hakim.

Wewenang lain dalam rangka menjaga dan menegakan kehormatan, keluhuran martabat serta perilaku hakim dalam prakteknya telah dipahami bahwa keberadaan KY dalam sistem ketatanegaraan merupakan lembaga yang bertugas mengawasi perilaku hakim, karena jika perilaku hakim dapat diawasi, dampak positif yang diinginkan agar hakim berperilaku 
yang mencerminkan keluhuran dan martabatnya sebagai pengadil.

Sebagai lambaga yang memiliki kewenangan mengawasi perilaku hakim, maka tidak salah jika sementara orang berpendapat KY memiliki "posisi" yang lebih tinggi/utama dari lembaga yang diawasi, dalam hal ini para hakim sebagai representasi MA sebagai lembaga pemegang kekuasaan kehakiman. Padahal kedudukan KY secara struktural adalah sederajat dengan MA dan MK. Akan tetapi secara fungsional peranan KY sebagai penunjang (auxiliary) terhadap lembaga kekuasaan kehakiman. ${ }^{10}$

Asumsi tersebut, dalam prakteknya telah menimbulkan kesan bahwa KY dengan segala "sepak terjangnya" di bawah kepemimpinan Busro Muqoddas mempunyai kedudukan yang lebih tinggi dari MA, terlebih setelah $\mathrm{KY}$ "menggeledah" ruang kerja Ketua MA waktu itu Bagir Manan. Tindakan penggeledahan ruang kerja Ketua MA telah mendorong beberapa hakim agung mengajukan judicial review atas UU No. 22 Tahun 2004 tentang Komisi Yudisial. Sejak itulah "perang terbuka" antara MA dengan KY dimulai, bahkan gagasan yang dilontarkan oleh KY untuk "kocok ulang" hakim agung telah mengakibatkan "ketersinggungan" di kalangan hakim agung dan menambah semangat untuk mewujudkan niatnya mengajukan review atas UU No. 22 tahun 2004 tentang KY.

Sejumlah 31 (tiga puluh satu) hakim agung akhirnya mengajukan permohonan dengan surat permohonannya bertanggal 10 Maret 2006 yang diterima dan terdaftar di Kepaniteraan Mahkamah Konstitusi Republik Indonesia (selanjutnya disebut Kepaniteraan Mahkamah) pada tanggal 14 Oktober 2005, dengan registrasi Nomor 005/PUU-IV/2006, yang telah diperbaiki secara berturut-turut dengan perbaikan permohonan bertanggal 17 Maret 2006, 27 Maret 2006 dan 29 Maret 2006.

Hakim MA tersebut di atas, sebenarnya mempersoalkan kaitan yuridis dan logis antara legislasi dan konstitusi. Penalaran mereka dike-

10 Jimly Asshiddiqie, 2006, Perkembangan dan Konsolidasi Lembaga Negara Pasca Reformasi, Jakarta: Sekretariat J enderal dan Kepaniteraan Mahkamah Konstitusi RI, hlm. 66 mas untuk menolak pengawasan $\mathrm{KY}$, pengertian kata "hakim" adalah hakim pada umumnya dan hakim karier, calon hakim agung, akan tetapi tidak mencakup hakim agung. Karena itu, tindakan KY mengawasi hakim agung, dan ketentuan UU KY 2004 yang terkait, harus dinyatakan bertentangan dengan konstitusi. Penalaran selanj utnya, pengertian "hakim" "tidak mencakup hakim konstitusi". ${ }^{11}$

Pemohon (31 hakim agung) mendalilkan bahwa ketantuan Pasal 1 butir 5 UU No. 22 Tahun 2004 tentang KY yang menentukan bahwa "Hakim adalah Hakim Agung dan Hakim pada badan peradilan disemua lingkungan peradilan yang barada dibawah Mahkamah Agung serta Hakim Mahkamah Konstitusi sebagaimana dimaksud dalam UUD RI 1945". Dengan demikian Pasal 1 butir 5 tersebut telah memperluas pengertian Hakim yang diatur dalam Pasal 24B ayat (1) UUD 1945 karena hanya dimaksudkan terhadap Hakim pada badan peradilan di semua lingkungan peradilan di bawah MA, tidak meliputi Hakim Agung dan Hakim Mahkamah Konstitusi. ${ }^{12}$ Terkait dengan permohonan bahwa pengertian hakim dalam Pasal 24B ayat (1) UUD 1945, tidak termasuk hakim agung oleh MA tidak dikabulkan dengan menyatakan bahwa, “... permohonan para Pemohon sepanjang menyangkut hakim agung tidak terdapat cukup alasan untuk mengabulkannya".

Pada bagian lain dari keputusan tersebut dinyatakan bahwa

UUKY terbukti tidak rinci mengatur mengenai prosedur pengawasan, tidak jelas dan tegas menentukan siapa subjek yang mengawasi, apa objek yang diawasi, instrumen apa yang digunakan serta bagaimana proses pengawasan itu dilaksanakan. Hal tidak jelas dan tidak rincinya pengaturan mengenai pengawasan dalam UUKY serta perbedaan dalam rumusan kalimat seperti dimaksud pada butir (i) menyebabkan semua ketentuan UUKY tentang pengawasan menjadi kabur (obscuur) dan menimbulkan keti-

\footnotetext{
11 Mohammad Fajrul Falaakh, MA-MK-KY Kekaburan Konstitusi, http:// www. unisosdem.org/article_detail. php? aid $=6563 \&$ coid $=3 \&$ caid $=21 \&$ gid $=3$, diunduh pada tanggal 3 Desember 2011.

12 Putusan Mahkamah Konstitusi No. 005/ PUU-IV/ 2006
} 
dakpastian hukum (rechtsonzekerheid) dalam pelaksanaannya; (iii) Konsepsi pengawasan yang terkandung dalam UUKY didasarkan atas paradigma konseptual yang tidak tepat, yaitu seolah-olah hubungan antara MA dan KY berada dalam pola hubungan check and balances" antar cabang kekuasaan dalam konteks ajaran pemisahan kekuasaan (separation of powers), sehingga menimbulkan penafsiran yang juga tidak tepat, terutama dalam pelaksanaannya. Jika ini dibiarkan tanpa penyelesaian, ketegangan dan kekisruhan dalam pola hubungan antara $\mathrm{KY}$ dan MA akan terus berlangsung dan kebingungan dalam masyarakat pencari keadilan akan terus meningkat, yang pada gilirannya juga dapat mendelegitimasi kekuasaan kehakiman yang akan dapat menjadikannya semakin tidak dipercaya; Oleh karena itu, segala ketentuan UUKY yang menyangkut pengawasan harus dinyatakan bertentangan dengan UUD 1945 dan tidak mempunyai kekuatan hukum mengikat karena terbukti menimbulkan ketidakpastian hukum (rechtsonzekerheid). ${ }^{13}$

Putusan MK tersebut di atas telah berakibat KY kehilangan "ruh" nya sebagai pengawas eksternal atas perilaku hakim di semua tingkatan dari hakim dalam lingkungan peradilan di bawah MA sampai dengan hakim agung. Memperhatikan hal tersebut, maka secara eksistensi KY tidak lagi mempunyai semangat dalam melaksanakan tugas, pokok dan fungsi sebagaimana diamanatkan dalam Pasal 24B UUD 1945, khususnya terkait dengan fungsi menjaga keluhuran martabat dan perilaku hakim.

Satu hal yang perlu diperhatikan, dari putusan MK tersebut di atas, masih memberikan kesempatan kepada lembaga yang berwenang membuat UU untuk melakukan perbaikan dan penyempurnaan serta harmonisasi UU tentang Kekuasaan Kehakiman, UU Komisi Yudisial dan UU Mahkamah Konstitusi. Putusan tersebut menurut pendapat penulis merupakan solusi yang "ditawarkan" oleh MK untuk mengakhiri "kebuntuan" dan "kegamangan" KY dalam melaksanakan tugas pokok dan fungsi pengawasan,

13 Ibid. khususnya fungsi melakukan pengawasan atas perilaku hakim.

Kegamangan KY dalam melaksanakan tugas pokok dan fungsnya, serta untuk "mengakhiri" ketidak harmonisan hubungan antara MA dengan KY, DPR bersama Pemerintah telah mengeluarkan UU No. 18 Tahun 2011 tentang Perubahan atas UU No. 22 Tahun 2004 tentang Komisi Yudisial, berdasarkan ketentuan UU No. 18 Tahun 2011, kewenangan KY justru mengalami penguatan kembali, dan khusus mengenai fungsi pengawasan terhadap perilaku hakim UU tersebut memberikan solusi. Hal tersebut sebagaimana diamanatkan dalam Pasal 19A dan Pasal 20.

Pasal 19A menentukan bahwa dalam rangka menjaga dan menegakkan kehormatan, keluhuran martabat, serta perilaku hakim, Komisi Yudisial berpedoman pada Kode Etik dan/ atau Pedoman Perilaku Hakim yang ditetapkan oleh Komisi Yudisial bersama Mahkamah Agung. Berdasarkan ketentuan tersebut, maka egoisme lembaga yang dipertontonkan oleh MA maupun $K Y$ terkait dengan kewenangan untuk mengawasi perilaku hakim dapat diselesaikan, hal ini disebabkan sebelum UU No. 18 Tahun 2011 diundangkan, kedua lembaga tersebut sama-sama merasa berhak untuk mengawasi perilaku hakim dengan alasan yang dikemukakan dapat dibenarkan secara normatif.

MA berpendapat bahwa berdasarkan ketentuan Pasal 32 ayat (2) UU No. 14 Tahun 1985, MA berwenang mengawasi tingkah laku dan perbuatan para hakim di semua lingkungan peradilan dalam menjalankan tugasnya. Sementara itu KY juga berpendapat, bahwa KY juga berwenang untuk mengawasi perilaku hakim, hal tersebut sebagaimana diamanatkan dalam Pasal 20 UU No. 22 Tahun 2004 tentang KY ditentukan bahwa dalam melaksanakan wewenang sebagaimana dimaksud dalam Pasal 13 huruf $b$ Komisi Yudisial mempunyai tugas melakukan pengawasan terhadap perilaku hakim dalam rangka menegakkan kehormatan dan keluhuran martabat serta menjaga perilaku hakim. Berdasarkan uraian tersebut di atas, maka dapat disimpulkan bahwa ketidak harmonisan hubungan antara MA dengan KY lebih disebab- 
kan karena persoalan legalitas mengenai kewenangan pengawasan yang dilakukan oleh baik MA maupun KY yang secara normatif memang UU yang menberika kewenangan kepada MA untuk mengawasi perilaku hakim bardasarkan UU No. 14 Tahun 1985 tentang MA ketikan itu belum dicabut atau dinyatakan tidak berlaku, dengan perkataan lain, hal tersebut juga disebabkan karena tidak adanya harmonisasi antara UU yang satu dengan yang lainnya yang mengatur materi yang sama.

Telah dikemukakan bahwa dengan UU N. 18 Tahun 2011 tentang KY, kewenangan KY semakin jelas dan diperkuat, hal tersebut sebagaimana diamanatkan dalam ketentuan Pasal 20 ayat (1) yang menegaskan bahwa

1. Dalam rangka menjaga dan menegakkan kehormatan, keluhuran martabat, serta perilaku Hakim, Komisi Yudisial mempunyai tugas:

a. melakukan pemantauan dan pengawasan terhadap perilaku Hakim;

b. menerima laporan dari masyarakat berkaitan dengan pelanggaran Kode Etik dan/ atau Pedoman Perilaku Hakim;

c. melakukan verifikasi, klarifikasi, dan investigasi terhadap laporan dugaan pelanggaran Kode Etik dan/atau Pedoman Perilaku Hakim secara tertutup;

d. memutuskan benar tidaknya Iaporan dugaan pelanggaran Kode Etik dan/atau Pedoman Perilaku Hakim; dan

e. mengambil langkah hukum dan/atau langkah lain terhadap orang perseorangan, kelompok orang, atau badan hukum yang merendahkan kehormatan dan keluhuran martabat Hakim.

Sementara itu Pasal 20 ayat (3), menentukan bahwa dalam rangka menjaga dan menegakkan kehormatan, keluhuran martabat, serta perilaku hakim sebagaimana dimaksud pada ayat (1) huruf a. Komisi Yudisial dapat meminta bantuan kepada aparat penegak hukum untuk melakukan penyadapan dan merekam pembicaraan dalam hal adanya dugaan pelanggaran Kode Etik dan/atau Pedoman Perilaku Hakim oleh Hakim. Sedangkan Pasal 20 ayat (4) menentukan bahwa aparat penegak hukum wajib menindaklanjuti permintaan Komisi Yudisial sebagaimana dimaksud pada ayat (3)".

Berdasarkan ketentuan tersebut, maka hubungan antara MA dengan KY memasuki era baru. Ketentuan mengenai hal tersebut diharapkan dapat menjadikan hubungan yang sinergi antara kedua lembaga negara tersebut. Dengan demikian hal tersebut dapat mewujudkan checks and balances. Walaupun Komisi Yudisial bukan pelaku kekuasaan kehakiman namun fungsinya berkaitan dengan kekuasaan kehakiman. ${ }^{14}$

Namun demikian yang perlu diperha-tikan bahwa mekanisme pengawasan eksternal yang terpisah dari pengawasan internal tidak akan dapat diterapkan di antara MA dengan KY, sepanjang didasarkan pada konsepsi checks and balances, karena checks and balances tidak dapat diterapkan oleh organ penunjang (auxiliary organ) terhadap organ utama (main organ)-nya sendiri. Pendirian yang menyatakan bahwa KY melakukan fungsi checks and balances terhadap MA, tidak sesuai dengan jiwa (spirit) konstitusi.

KY sebagai auxiliary organ kekuasaan yudikatif akan mengalami kesulitan dalam melaksanakan kewenangannya jika didasarkan pada pemikiran checks and balances demikian, karena akan menimbulkan mekanisme yang mengandung cacat konstitusional (constitutional defect) dan sekaligus tidak efektif, yang pada akhirnya akan melahirkan krisis yang mencederai tingkat kepercayaan terhadap lembaga dan proses peradilan. Tanpa komunikasi antara lembaga negara utama (main organ) dan lembaga negara penunjang (auxiliary organ) yang didasarkan atas prinsip saling menghormati dan saling mendengar, keberadaan lembaga negara penunjang (auxiliary organ) demikian hanya akan dianggap sebagai kendala terhadap sistem ketatanegaraan secara keseluruhan yang didasarkan atas paham constitutional. ${ }^{15}$

Memperhatikan hal tersbut di atas, maka salah satu hal yang sangat penting untuk menciptakan hubungan yang harmonis antara MA dengan KY ke depan perlu kiranya dibangun

14 Lihat Penjelasan Umum UU No. 18 Tahun 2011

15 Lihat Putusan Mahkamah Konstitusi No. 005/ PUU-IV/ 2006 
model komunikasi antara lembaga utama (main organ) dengan lembaga negara penunjang (auxiliary organ) dengan prinsip saling hormat menghormati, dan saling mendengar dengan prinsip keterbukaan dan tanpa saling curiga dan syuhudlon. Prasangka baik antara MA dengan KY harus ditumbuh kembangkan melalui pembentukan sistem/ kebijakan dalam bentuk peraturan perundang-undangan dalam rangka mewujudkan kekuasaan kehakiman yang merdeka dalam rangka menegakan hukum dan keadilan sebagaimana diamanatkan dalam ketentuan Pasal 24 ayat (1) UUD 1945 hasil amandemen.

Menurut penulis "gonjang-ganjing" yang terjadi dan menyertai perjalanan kedua lembaga negara tersebut lebih disebabkan karena faktor ego dan harga diri, serta kepemimpinan. Faktor ego, harga diri dan kepemimpinan menjadi sangat menentukan harmonis tidaknya hubungan antara kedua lembaga negara tersebut. Kita masih mudah mendengarkan statement yang dikeluarkan oleh kedua pemimpin MA dan KY, Ketua MA Harifin A Tumpa mengkritik keras KY. Bahkan, Harifin menyebut sebagian anggota KY tidak paham hukum acara.

Perseteruan tersebut tidak hanya perang urat syaraf. Namun sampai tingkat kepolisian. Yaitu MA mempolisikan komisioner KY, Suparman Marzuki pada Senin (11/7/2011) dengan tuduhan melakukan penghinaan kepada MA. Dalam pemberitaan salah satu media nasional Suparman menyebut seseorang harus membayar uang sebesar Rp 300 juta untuk menjadi hakim dan Rp 275 juta untuk menjadi Ketua Pengadilan Negeri di Jakarta. Mendapati ancaman pidana ini, Suparman pun langsung angkat bendera putih. Alhasil, MA pun mencabut laporannya. "Atas permintaan maaf itu maka Ketua MA selaku pimpinan tertinggi dari lembaga MA dengan bijak menerima permintaan maaf itu," beber Peter. ${ }^{16}$

Perubahan kepemimpinan KY dari Busyro Muqoddas ke Erman Suparman ternyata tidak menjadikan hubungan MA dengan KY mem-baik, seperti diberitakan kasus yang aktual, KY telah

16 http:// www. detiknews. com/ read/ 2011/ 08/ 15/ 0422 06/ 1703572/ 10/ ma-vs-ky-seteru-lembaga-tingginegara-yang-tak-kunjung-usai?nd992203605 menuntaskan proses eksaminasi persidangan perkara Antasari di tingkat pengadilan pertama atas permintaan kuasa hukum Antasari, bahwa ada dugaan pelanggaran kode etik yang dilakukan oleh tiga orang hakim PN J aksel yang menyidangkan perkara mantan ketua KPK itu. Ketiga hakim tersebut yakni ketua majelis Herry Swantoro, Ibnu Prasetyo dan Nugroho Setiadji. Dalam rekomendasinya KY meminta MA untuk memberhentikan sementara atau non-palu selama 6 bulan terhadap hakim yang menyidangkan perkara Antasari, dan dibentuknya Majelis Kehormatan Hakim. Namun rekomendasi KY ini ditolak MA dengan tegas. ${ }^{17}$

Bahkan Ketua MA Harifin A Tumpa seperti dikutip Kantor Berita Antara 12 Agustus 2011 mengungkapkan, pihaknya pasti menolak rekomendasi KY jika hal itu memang menyangkut putusan hakim. Pasalnya hakim memiliki judicial imunity yang berlaku secara universal. yang diputuskan hakim adalah keyakinan hakim, kecuali kalau mereka memutus itu melakukan hal-hal yang dilarang, seperti misalnya menerima suap, dan mendapat pengaruh-pengaruh lain. MA berkeyakinan wilayah teknis yudisial adalah wilayah hakim yang tidak boleh diganggu gugat oleh siapapun. Hakim memiliki independensi dalam memutus perkara sesuai dengan keyakinan hakim yang bersangkutan. Pengawasan yang dilakukan oleh KY selama ini menyeruak ke wilayah terlarang, yaitu teknis yudisial. ${ }^{18}$ Padahal untuk mengantisipasi KY agar dalam melakukan pengawasan tidak masuk ke dalam wilayah yudisial, dan untuk ntuk menghindari kemungkinan terjadinya perilaku yang "sok" kuasa dari para komisioner dalam melakukan tugas pokok dan fungsinya, terutama yang berkaitan dengan pelaksanaan pengawasan hakim, KY telah mengeluarkan Peraturan Komisi Yudisial No. 3 Tahun 2011 tentang Pengawasan Hakim, di mana dalam Pasal 2 ditegaskan bahwa

\footnotetext{
17 http:// www. detiknews.com/ read/ 2011/ 09/ 13/ 10185 3/ 1720907/ 10/ bawa-kasus-antasari-ke-mk-ky-dinil

18 Sri Tofani dan Nur Agus Susanto, "13 Tahun Independensi Kekuasaan Kehakiman Mengembalikan Marwah "Wakil Tuhan" Buletin Komisi Yudisial Republik Indonesia J akarta, VI (1) Agustus-September 2011, hIm. 34
} 
1. Pengawasan hakim tidak boleh mengurangi kebebasan hakim dalam memeriksa dan memutus perkara.

2. Dalam melaksanakan pengawasan hakim, Komisi Yudisial wajib :

a. menjaga kemandiriannya serta mentaati norma dan peraturan perundang-undangan;

b. menjaga kerahasiaan keterangan yang karena sifatnya merupakan rahasia Komisi yudisial yang diperoleh berdasarkan kedudukannya sebagai anggota Komisi Yudisial.

MA sebagai lembaga yang eksistensinya selalu ada dalam setiap konstitusi atau UUD yang pernah berlaku di Indonesia, dan mampunyai kedudukan yang sangat startaegis sebagai kekuasaan yang merdeka dan terbebas dari pengaruh kekuasaan lain dalam rangka menegakan hukum dan keadilan, barangkali "merasa" kemunculan KY dalam sistem ketatanegaraan berdasarkan UUD hasil amandemen dapat mengancam kemerdekaan dan kemndirian kekuasaan kehakiman.

Keberadaan KY tidak dimaksudkan untuk mengurangi kemerdekaan dalam kekuasaan kehakiman dalam menyelenggarakan peradilan, karena mahkota dari peradilan adalah kebebasannya yang harus dij aga dari pengaruh kekuasaan manapun juga. Namun kebebasan kekuasaan kehakiman bukanlah merupakan hak preogatif dari kekuasaan kehakiman tetapi justru dalam negara hukum kebebasan tersebut lebih merupakan kewajiban dari kekuasaan kehakiman dan hak dari pencari keadilan. ${ }^{19}$

Menurut penulis, kekuasaan kehakiman yang merdeka dan terbebas dari pengaruh kekuasaan lain jangan diartikan sebagai kemandirian yang mutlak tanpa batas, karena itu kemandirian kekuasaan kehakiman harus diartikan sebagai kemandirian atau kebebasan yang relatif. Hal tersebut karena kemandirian kekuasaan keahikaman dapat dibatasi oleh beberapa hal, yaitu peraturan perundang-undangan, kehendak para pihak, kesusilaan dan ketertiban.
Selama hampir satu tahun Komisi Yudisial (KY) berdiri perubahan yang signifikan di dalam memberantas mafia peradilan dan tercapainya reformasi hukum belum dapat terwujud secara maksimal, yang sejauh ini dapat digambarkan sebagai keberhasilan dari KY adalah adanya simpati publik yang besar akan terciptanya suatu lembaga peradilan yang bersih berdasarkan pada tindakan-tindakan yang telah dilakukan KY. Ke depan, KY diharapkan dapat membuat suatu pendapat ataupun opini untuk menciptakan musuh bersama bagi masyarakat dalam hal ini adalah hakim-hakim yang bejat, yang tidak kredibel dan sebagainya untuk diberantas. Walaupun hadirnya KY baru sebatas menciptakan simpati publik namun hal ini tetap juga suatu prestasi yang harus tetap dipelihara dan dikem- bangkan. Apabila nanti KY berhasil menggiring opini publik untuk menjadikan mafia peradilan sebagai musuh bersama bagi masyarakat untuk diberantas maka ini akan menjadi prestasi yang luar biasa. ${ }^{20}$

KY dengan kewenangan yang dimiliki untuk mengawasi perilaku para hakim maka kemudian muncullah resistensi dari jajaran hakim akan tugas dan fungsi ini. Tetapi di mata ketua Konsorsium Reformasi Hukum Nasional ini KY berdiri justru bukan untuk mengganggu independensi para hakim melainkan malah meneguhkan atau mengukuhkan independensi itu sendiri. Munculnya resistensi terhadap eksistensi KY sebetulnya disebabkan oleh adanya cara pandang yang berbeda antara para hakim agung di Mahkamah Agung (MA) dengan Komisi Yudisial. Poin yang belum dapat diterima MA saat ini adalah bahwa KY dapat mengawasi prilaku para hakim sampai kepada persoalan-persoalan yang ada pada tataran teknis yudisial seperti menyangkut tentang putusan. Sebenarnya hal ini tidak menjadi masalah karena pemeriksaan terhadap putusan yang telah dikeluarkan ini hanya menjadi suatu pintu masuk bagi KY dalam melaksanakan tindakan pengawasan selama KY tidak mengubah putusan

20 Firman Arifin, "Resistensi Terhadap Komisi Yudisial Disebabkan Cara Pandang Yang Berbeda", Buletin Komisi Yudisial Republik Indonesia, hlm. 14 
itu, apalagi hasil dari tindakan pengawasan oleh $\mathrm{KY}$ ini hanya sebatas rekomendasi yang nanti pelaksanannya akan ditentukan oleh Mahkamah Agung. Sampai sejauh ini hampir semua rekomendasi yang telah dikeluarkan oleh $\mathrm{KY}$ belum ditindaklanjuti oleh MA sehingga hal ini menjadi persoalan terhadap legitimasi KY. Padahal menurut UUD 1945 telah jelas dikatakan bahwa objek pengawasan dari $\mathrm{KY}$ mencakup semua unsur hakim baik itu hakim mulai tingkat pengadilan negeri, pengadilan tinggi, dan juga hakim agung bahkan termasuk hakim konstitusi. ${ }^{21}$

Sebagaimana telah diutarakan, bahwa perubahan UU No. 22 Tahun 2004 dengan UU No. 18 Tahun 2011 tentang Perubahan UU No. 22 Tahun 2004 tentang Komisi Yudisial, sebenarnya harus dipahami oleh setiap warga masyarakat yang mendambakan tegaknya hukum dan keadilan, bahwa perubahan tersebut tidak lain merupakan upaya normatif bangsa ini dalam rangka memformat ulang hubungan antara MA dengan $K Y$ yang sejak eksistensi $K Y$ ada dalam sistem ketatanegaraan Indonesia, selalu mengalami pasang naik dan surut. Beberapa pasal yang berusaha memberikan solisi demi terciptanya hubungan yang harmonis antara MA dengan $K Y$, disamping pasal-pasal yang telah disebutkan di atas, seperti Pasal 13, Pasal 19A, Pasal 20, juga dapat dijumpai dalam beberapa pasal lainnya, seperti Pasal 22 ayat (3), (4) dan (5) UU No. 18 Tahun 2011.

Pasal 13 ayat (1), (2) dan (3) yang menentukan bahwa Komisi Yudisial mempunyai wewenang:

1. Mengusulkan pengangkatan hakim agung dan hakim ad hoc di Mahkamah Agung kepada DPR untuk mendapatkan persetuj uan;

2. Menjaga dan menegakkan kehormatan, keluhuran martabat, serta perilaku hakim;

3. Menetapkan Kode Etik dan/atau Pedoman Perilaku Hakim bersama-sama dengan Mahkamah Agung;

Kemudian Pasal 22 menentukan bahwa :

1. Pimpinan Mahkamah Agung meminta kepada Badan Peradilan dan/atau Hakim untuk memberikan keterangan atau data sebagaimana dimaksud pada ayat (3) dalam jangka waktu 14 (empat belas) hari terhitung sejak tanggal permintaan Komisi Yudisial.

2. Menentukan bahwa Apabila Badan Peradilan dan/ atau Hakim belum memberikan keterangan atau data dalam jangka waktu sebagaimana dimaksud pada ayat (2), Komisi Yudisial meminta keterangan dan/ atau data tersebut melalui pimpinan MA.

3. Pimpinan Mahkamah Agung meminta kepada Badan Peradilan dan/atau Hakim untuk memberikan keterangan atau data sebagaimana dimaksud pada ayat (3) dalam jangka waktu 14 (empat belas) hari terhitung sejak tanggal permintaan Komisi Yudisial.

4. Apabila permintaan sebagaimana dimaksud pada ayat (2) dan ayat (4) tidak dipenuhi tanpa alasan yang sah, pimpinan Badan Peradilan atau Hakim yang bersangkutan dikenai sanksi sesuai dengan peraturan perundang-undangan.

Ketentuan dalam UU No. 18 Tahun 2011 yang juga harus dijadikan pedoman awal untuk menciptakan hubungan yang saling menghormati antara MA dan KY dapat dijumpai dalam ketentuan Pasal 22 ayat (5) yang menentukan bahwa Pimpinan Mahkamah Agung meminta kepada Badan Peradilan dan/atau Hakim untuk memberikan keterangan atau data sebagaimana dimaksud pada ayat (3) dalam jangka waktu 14 (empat belas) hari terhitung sejak tanggal permintaan Komisi Yudisial.

Pasal 22 ayat (5) UU No. 18 Tahun 2011 tersebut secara normatif merupakan dukungan yang harus dilakukan oleh MA untuk memberikan "desakan" kepada lingkungan para hakim dan/atau badan-badan peradilan di bawahnya, yang meliputi peradilan umum, peradilan militer, peradilan agama dan peradilan tata usaha negara untuk memberikan segala sesuatu baik yang berupa data maupun keterangan yang diminta oleh $\mathrm{KY}$. Ketentuan tersebut tentunya menjadi kekuatan baru kepada KY agar dapat melaksanakan tugas pokok dan fungsinya dalam rangka menegakan keluhuran serta perilaku hakim.

21 Ibid. 
Pasal 22D ayat (1) juga menentukan bahwa dalam hal dugaan pelanggaran Kode Etik dan/atau Pedoman Perilaku Hakim dinyatakan terbukti sebagaimana dimaksud dalam Pasal $22 \mathrm{C}$ huruf a, Komisi Yudisial mengusulkan penjatuhan sanksi terhadap Hakim yang diduga melakukan pelanggaran kepada Mahkamah Agung. Ketentuan tersebut sebenarnya secara substansi tidak ada perbedaan dengan ketentuan yang terdapat dalam UU No. 22 Tahun 2004 tentang KY, bahwa KY dapat memberikan rekomendasi penjatuhan sanksi kepada hakim yang diduga melanggar kode etik, hal tersebut sebagaimana dimaksud dalam Pasal 21 UU No. 22 Tahun 2004 yang menegaskan bahwa untuk kepentingan pelaksanaan kewenangan sebagaimana dimaksud dalam Pasal 13 huruf $b$, Komisi Yudisial bertugas mengajukan usul penjatuhan sanksi terhadap hakim kepada pimpinan Mahkamah Agung dan/ atau Mahkamah Konstitusi.

Berdasarkan ketentuan tersebut, maka MA tidak dapat "dipaksa" oleh KY atau siapapun di negeri ini untuk melaksanakan rekomendasi yang telah diberikan oleh $\mathrm{KY}$ terkait dengan pelanggaran kode etik ataupun yang terkait dengan perlaku hakim, artinya MA dalam posisi dapat menerima dan kemudian menjalankan rekomendasi KY untuk menjatuhkan sanksi terhadap hakim yang diduga melanggar dan berperilaku yang tidak terpuji, namun di sisi lain MA juga tidak wajib melaksanakan rekomendasi tersebut, bahkan sampai sebelum UU No. 22 Tahun 2004 dirubah, rekomendasi yang diberikan oleh KY kepada MA "hanya" disimpan dan diadministrasikan secara baik, namun tidak dilaksanakan.

Permasalahan tersebut tentunya akan tidak terulang kembali, karena berdasarkan UU No. 18 Tahun 2011, MA "dipaksa" untuk menindaklanjuti rekomendasi yang telah diberikan oleh $\mathrm{KY}$, hal tersebut sebagaimana diatur dalam Pasal 22D ayat (3) yang menentukan bahwa Mahkamah Agung menjatuhkan sanksi terhadap Hakim yang melakukan pelanggaran Kode Etik dan/atau Pedoman Perilaku Hakim yang diusulkan oleh Komisi Yudisial dalam waktu paling lama 60 (enam puluh) hari terhitung sejak tanggal usulan diterima.
Berdasarkan ketentuan tersebut pandangan MA selama ini yang berpendapat bahwa sebuah rekomendasi atau dengan kata lain "saran" tidak mempunyai kualitas "harus" dilaksanakan, sejak saat diundangkannya UU No. 18 Tahun 2011 harus dibuang jauh-jauh, karena politik hukum perundang-undangan yang tercermin dalam perubahan UU No. 22 Tahun 2004 tersebut telah memberikan garis yang sangat jelas, tegas dan lugas dalam menentukan "nasib" sebuah rekomendasi dari KY.

Upaya memperbaiki harmonisasi hubungan MA dengan $K Y$ tidak hanya sebatas itu, karena Pasal lainnya yakni Pasal 22E yang juga menentukan bahwa:

1. Dalam hal tidak terjadi perbedaan pendapat antara Komisi Yudisial dan Mahkamah Agung mengenai usulan Komisi Yudisial tentang penjatuhan sanksi dan Mahkamah Agung belum menjatuhkan sanksi dalam jangka waktu sebagaimana dimaksud dalam Pasal 22D ayat (3) maka usulan Komisi Yudisial berlaku secara otomatis dan wajib dilaksanakan oleh Mahkamah Agung.

2. Dalam hal terjadi perbedaan pendapat antara Komisi Yudisial dan Mahkamah Agung mengenai usulan Komisi Yudisial tentang penjatuhan sanksi ringan, sanksi sedang, dan sanksi berat selain sebagaimana dimaksud dalam Pasal 22D ayat (2) huruf c angka 4 dan angka 5), dilakukan pemeriksaan bersama antara Komisi Yudisial dan Mahkamah Agung terhadap Hakim yang bersangkutan.

3. Dalam hal Mahkamah Agung dan Komisi Yudisial dalam jangka waktu sebagaimana dimaksud dalam Pasal 22D ayat (3) tidak mencapai kata sepakat sebagaimana dimaksud pada ayat (2), maka usulan Komisi Yudisial sepanjang memenuhi ketentuan dalam Pasal 22B ayat (1) huruf a, berlaku secara otomatis dan wajib dilaksanakan oleh Mahkamah Agung (garis bawah penulis).

4. Ketentuan mengenai tata cara pemeriksaan sebagaimana dimaksud pada ayat (1) diatur bersama oleh Komisi Yudisial dan Mahkamah Agung. 
Berdasarkan urian tersebut di atas, maka dapat dikatakan bahwa keberadaan UU No. 18 Tahun 2011 secara normatif telah memberikan garis mengenai relasi antara MA dengan $\mathrm{KY}$ yang tidak lagi menempatkan seolah-olah KY mempunyai kedudukan yang paling tinggi di antara lembaga negara sebagaimana diatur dalam Bab IX UUD 1945 tentang Kekuasaan Kehakiman. Kedudukan KY sebenarnya "hanya" merupakan lembaga negara independen yang diharapkan dapat mendukung terselenggaranya kekuasaan kehakiman yang merdeka dalam rangka menegakan hukum dan keadilan, artinya sejauh ada jaminan dari para penegak hukum (khususnya dalam hal ini hakim) hukum dapat ditegakan dan keadilan dapat tercipta di bumi Indonesia ini, sebenarnya eksistensi KY dapat ditiadakan, sekalipun proses dan mekanisme untuk "meniadakan" KY juga bukan merupakan hal yang mudah, karena hanya dapat dilakukan melalui mekanisme amandemen UUD 1945, padahal momentum perubahan UUD 1945 menurut penulis sudah berlalu dan tidak tepat lagi dilaksanakan sekaran.

Memperhatikan uraian tersebut di atas, maka dapat disimpulkan bahwa pasang surut hubungan antara MA dengan KY dalam sistem ketatanegaraan RI di samping disebabkan karena terjadi disharmonisasi antara peraturan perundang-undangan yang ada, khususnya di bidang yang berkaitan dengan kekuasaan kehakiman, seperti UU tentang Kekuasaan Kehakiman, UU tentang Mahkamah Agung, UU tentang Mahkamah Konstitusi dan juga UU tentang Komisi Yudisial, juga disebabkan karena karakter kepemimpinan yang ada dikedua lembaga negara tersebut.

Disharmonisasi hubungan antara MA dengan KY bisa juga disebabkan karena adanya pemahaman yang tidak sama antara MA dengan $\mathrm{KY}$ terkait dengan hakekat pengawasan dalam mekanisme ketata-negaraan. Menurut penulis pengawasan sebenarnya merupakan hal yang biasa dan lumrah adanya dalam sebuah organisasi termasuk ornagisasi negara, dan setiap kekuasaan yang dimiliki oleh lembaga-lembaga negara termasuk di dalamnya MA dan KY harus dapat dipertanggung jawabkan. Oleh karena itu sikap dan pendirian yang sering kita dengar bahwa hakim mempunyai kebebasan dan kemandirian dalam memutus perkara yang tidak bisa diganggu gugat mestinya tidak dipahami secara "membabi buta" dan zaklijke, karena jika dipahami secara zaklijke dapat mengakibatkan penyalahgunaan kebebasan dan kemandirian tersebut. Ini justru yang menjadi berbahaya, oleh karena itu meniadakan lembaga pengawasan eksternal, dalam hal ini $K Y$ atas pelaksanaan kekuasaan kehakiman, justru merupakan upaya yang tidak sejalan dengan eksistensi kekuasaan kehakiman dalam sistem ketatanegaraan RI, yakni sebuah kekuasaan yang merdeka dalam rangka menegakan hukum dan keadilan.

Langkah yang perlu di ambil dalam mewujudkan harmonisasi hubungan antara MA dan KY sebagaimana telah dikatakan di atas, salah satu cara yang dapat ditempuh adalah membangun komunikasi intensif dengan membuang jauh-jauh perasaan dan ego bahwa salah satu merasa lebih superior dari yang lain. Eksistensi MA dan KY ibarat dua sisi mata uang yang walaupun berbeda, keduanya sama-sama penting dalam dan dibutuhkan dalam rangka mewujudkan cita-cita nasional yakni masyarakat Indonesia yang adil dalam kemakmuran dan makmur dalam keadilan. Langkah yang lainnya, dan sekarang sudah dilaksanakan adalah melakukan harmonisasi peraturan perundang-undangan yang berkaitan denggan implementasi kekuasaan kehakiman.

\section{Penutup \\ Simpulan}

Hubungan antara Mahkamah Agung dengan Komisi Yudisial mengalami ketidak-harmunisan dalam sistem ketatanegaraan Republik Indonesia disebabkan karena Pertama adanya disharmonisasi antara peraturan perundang-undangan di bidang kekuasaan kehakiman yang meliputi undang-undang tentang Kekuasaan Kehakiman, undang-undang tentang Mahkamah Agung, undang-undang Mahkamah Konstitusi dan undangundang tentang Komisi Yudisial. Kedua karakter kepemimpinan yang ada di Mahkamah Agung dan Komisi Yudisial yang terlalu mengedepan- 
kan ego bahwa salah satu merasa lebih superior dari yang lain.

Untuk menciptakan hubungan yang harmonis antara Mahkamah Agung dengan Komisi Yudisial pada masa yang akan datang harus di lakukan dengan membangun model komunikasi antara lembaga utama (main organ), dalam hal ini Mahkamah Agung dengan lembaga negara penunjang (auxiliary organ) dengan prinsip saling hormat menghormati, dan saling mendengar dengan prinsip keterbukaan dan tanpa saling curiga dan syuhudlon.

\section{Rekomendasi}

Mencermati hal di atas, penulis memberikan rekomendasi berupa Pertama, Mahkamah Agung sebagai pelaksana kekuasaan kehakiman yang merdeka dalam rangka menegakan hukum dan keadilan memang tidak bisa diganggu gugat oleh siapapun termasuk oleh Komisi Yudisial. Mahkamah Agung mempunyai kemandirian dalam proses yudisial, namun demikian, hal tersebut tidak boleh dipahami secara mutlak, karena pemahaman yang keliru tentang kemandirian dan kemerdekaan kekuasaan kehakiman dapat menimbulkan kecenderungan penyalahgunaan kekuasaan, serta perlu dipahami bahwa setiap kekuasaan dalam sistem ketatanegaraan harus dapat dipertanggungj awabkan, bukan hanya kepada ALLAH SWT, melainkan juga kepada rakyat sebagai pemilik kedaulatan; Kedua, Komisi Yudisial dalam melaksanakan pengawasan terhadap perilaku hakim, tidak boleh masuk ke ranah yudisial, karena dapat "mengancam" kebebasan dan kemandirian hakim yang telah dijamin oleh UUD 1945.

\section{Daftar Pustaka}

Arifin, Firman. "Resistensi Terhadap Komisi Yudisial Disebabkan Cara Pandang Yang Berbeda", Buletin Komisi Yudisial Republik Indonesia, Vol. VI No. 1 Agustus-September 2011;

Arinanto, Satya. "Reformasi Hukum, Demokrasi, dan Hak Asasi Manusia" - J urnal Hukum dan Pembangunan Jakarta, Tahun XXVIII No. 1-3 Januari -J uni 1998, Fakultas Hukum UI:
Asshiddiqie, Jimly. 2005. Lembaga Negara dan Sengketa Kewenangan Antar Lembaga Negara, Jakarta: Konsorsium Reformasi Hukum Nasional (KRHN) bekerjasama dengan Mahkamah Konstitusi;

-.---.--. 2006. Perkembangan dan Konsolidasi Lembaga Negara Pasca Reformasi. J akarta: Sekretariat J enderal dan Kepaniteraan Mahkamah Konstitusi Rl;

Falaakh, Mohammad Fajrul. MA-MK-KY Kekaburan Konstitusi, http:// www. unisosdem.org/article_detail.php? aid 6563\&co $i d=3 \&$ caid $=21 \&$ gid $=3$, diunduh pada tanggal 3 Desember 2011.

Fauzan, Muhammad. "Eksistensi Komisi Yudisial Dalam Struktur Ketatanegaraan Republik Indonesia dan Yang Seharusnya Diatur daIam Peraturan-Perundang", J urnal Dinamika Hukum Vol. 8 No. 1 J anuari 2008, FH UNSOED Purwokerto;

"Kewenangan Mahkamah Konstitusi dalam Proses Impeachment Presiden Menurut Sistem Ketatanegaraan Republik Indonesia". Jurnal Dinamika Hukum Vol. 11 No. 1 J anuari 2011, FH UNSOED Purwokerto;

Harjono. "Lembaga Negara Dalam UUD 1945". J urnal Konstitusi Vol. 4 No. 2 J uni 2001;

Masrur, Devica Rully. "Implikasi Putusan Mahkamah Konstitusi Dalam Pengujian UU No. 22 Tahun 2004 Tentang Komisi Yudisial Terhadap Pengawasan Perilaku Hakim". J urnal Hukum Kebijakan Publik RES REPUBLICA Vol. 1 No. 1 September 2007, FH UNS Surakarta;

Thohari, Ahsin "Komisi Yudisial dalam Ketatanegaraan Indonesia", Majalah Pakar J akarta, Vol. II No. 6 J uni 2003;

-.. 2004. Komisi Yudisial dan Reformasi Peradilan, J akarta: ELSAM;

Tofani, Sri dan Nur Agus Susanto."13 Tahun Independensi Kekuasaan Kehakiman Mengembalikan Marwah "Wakil Tuhan". Buletin Komisi Yudisial Republik Indo-nesia Jakarta, Vol. VI No. 1 Agustus-September 2011; 